\title{
Simulation studies of selected characteristics of the injection system the common rail medium-speed research engine
}

\begin{abstract}
Injection Systems of Common Rail type are becoming widely used in marine engines. The aim of the research and development of these systems is to optimize the multi-injection process. The authors of the paper present the results of research on the fuel supply system of research common-rail marine medium-speed engine. The study was conducted for the nominal circulation engine speed. For the analysis were established three variants of fuel supply - a single dose, two-piece and three-piece The interdependence of measured injection parameters and their effect on engine operation have been presented in graphical form.
\end{abstract}

Key words: common rail, fuel injection characteristics, single dose and multi-piece dose

\section{Badania symulacyjne wybranych chrakterystyk wtrysku ukladu typu common rail średnioobrotowego okrętowego silnika badawczego}

\begin{abstract}
Układy wtryskowe typu common rail znajduja coraz szersze zastosowanie w okrętowych silnikach spalinowych. W badaniach rozwojowych tych układów dąży się do wielokryterialnej optymalizacji przebiegu procesu wtrysku. Autorzy referatu przedstawiaja wyniki badań instalacji zasilania paliwem uktadu typu common rail średnioobrotowego okrętowego silnika badawczego. Badania przeprowadzono dla nominalnej prędkości obrotowej silnika Do analizy przyjęto trzy warianty zasilania paliwem: dawkę pojedyncza, dwuczęściowa i trzyczęściowa. Przedstawiono w formie graficznej wzajemne zależności pomierzonych parametrów wtrysku paliwa, a także ich wpływ na pracę silnika.
\end{abstract}

Słowa kluczowe: system common rail, charakterystyka wtrysku paliwa, podziat dawki wtrysku

\section{Introduction}

The need to obtain relevant characteristics of the fuel injection which would ensure the desired combustion process has led the use of electronic control of fuel injection into the cylinders of combustion engines. The electronic fuel injection systems $[1-6]$ have been developing dynamically which can also be observed with marine diesel engines [7, 8]. For several years low-speed ( $\mathrm{n}=70 \div 240 \mathrm{rpm}$ ) engines produced by Wärtsilä RT-flex type and the MAN B \& W LM-E have been used on ships. The later company has replaced the fuel injection pump (with adjustable dosage overflow valves) with the electronically controlled hydraulic cylinder supplying the conventional injectors. The Wärtsilä Company used a common rail with the Wärtsilä Engine Control System 9500 (WECS-9500). This system electronically controls the operation of injectors as well as controls the operation of start and exhaust valves and pumps of the cylinder lubrication system. Input parameters of this control system are: given and actual engine speed, type of fuel and its maximum dose limited by the operator.

Medium-speed engines $(\mathrm{n}=240 \div 1200 \mathrm{rpm})$ are also fitted with the fuel injection systems of CR type. Lifting of the needle in the injectors of these engines is either electromagnetically operated (for the amount of fuel less than 45 $\mathrm{mm}^{3} / \mathrm{ms}$ ) or traditionally controlled by hydraulic amplifiers.

The CR systems in the high-speed engines $(\mathrm{n}=1200 \div$ $\div 2500 \mathrm{rpm}$ ) are analogous to the once used in the automobile industry. Piezoquarts injectors are used in these engines because of the value of injection pressure and the division of fuel delivery into several parts (phases).

\section{Wstęp}

Konieczność uzyskania odpowiednich charakterystyk procesu wtrysku paliwa, zapewniających pożądany przebieg procesu spalania spowodowała zastosowanie sterowania elektronicznego wtryskiem paliwa do cylindrów silników spalinowych. Nastąpił dynamiczny rozwój stosowania układów elektronicznego wtrysku paliwa [1 - 6], co odnosi się również do okrętowych silników spalinowych [7,8]. Od kilku lat wolnoobrotowe ( $\mathrm{n}=70 \div 240 \mathrm{obr} / \mathrm{min}$ ) silniki firmy Wärtsilä typu RT-flex i firmy MAN B\&W typu LM-E stosowane są na statkach. Ta ostatnia firma zastąpiła pompę wtryskową paliwa $\mathrm{z}$ regulacją dawkowania zaworami przelewowymi sterowanym elektronicznie siłownikiem hydraulicznym, zasilającym tradycyjne wtryskiwacze. Firma Wärtsilä zastosowała system zasobnikowy typu common rail, sterując elektronicznie działaniem wtryskiwaczy za pomocą systemu Wärtsilä Engine Control System - 9500 (WECS-9500), który dodatkowo steruje pracą zaworów wylotowych i rozruchowych silnika oraz pracą pomp układu smarowania cylindrów. Wielkościami wejściowymi tego układu sterowania są: zadana i rzeczywista prędkość obrotowa i kątowa wału korbowego silnika, rodzaj paliwa i jego maksymalna dawka ograniczona nastawą dokonywaną przez operatora.

Silniki średnioobrotowe $(\mathrm{n}=240 \div 1200 \mathrm{obr} / \mathrm{min})$ również wyposażane są coraz częściej w układy wtrysku paliwa typu common rail (CR). Wtryskiwacze tych silników mają sterowane elektromagnetycznie uniesienie iglicy (dla dawki paliwa mniejszej niż $45 \mathrm{~mm}^{3} / \mathrm{ms}$ ) lub tradycyjne - sterowane wzmacniaczami hydraulicznymi. 
Each of the systems of electronic control of fuel injection may usually control the injection angle, fuel delivery and the distribution of this dose in the injection process in time (crank angle). This new quality of fuel injection has been achieved not only by using the electronic control system, but also by applying new executive elements, such as highpressure plunger pump, electronically controlled overflow valves, hydraulic accumulator and electronically controlled fuel injectors.

The aforementioned factors have enabled a radical change in fuel injection control and in conditions for optimum combustion process (according to minimum fuel consumption or the desired nitrogen oxides emission).

Further development of electronic systems of fuel injection control requires investigating many fuel injection characteristics. Such research is performed in many national and international $R \& D$ centers with the use of special stands i.e. fuel rate indicators or research engines [8-11]. The authors conduced such research in the Naval Academy in Gdynia on a test stand, which had been made by the University of Bielsko-Biala team supervised by prof. Z. Stelmasiak. This stand with a fuel rate indicator had been designed by the authors of this publication for 1DR6 research engine test bed in the laboratory of the Naval Academy in Gdynia [2].

\section{Description of the research stand}

As it has been mentioned, the test stand (Fig. 1) differed from an ordinary engine injection system because the fuel rate indicator was used instead of the combustion chamber. The indicator enabled measurement of the amount of fuel and, most importantly, it allowed to record the wave phenomena associated with fuel injection. An additional device in the test stand is the controller which controls the injection rate, the number of injection, time of injection and intervals between injection stages (the controller is designed so as to allow the division of the injection into 5 parts). The controller also allows the measurement and recording of following parameters: fuel

W silnikach szybkoobrotowych $(\mathrm{n}=1200 \div 2500$ obr/min) stosowane są układy typu CR analogiczne do stosowanych w motoryzacji. Z uwagi na wartość ciśnienia wtrysku oraz podział dawki paliwa na kilka części (faz) stosowane są wtryskiwacze piezokwarcowe.

Każdy z układów elektronicznego sterowania wtryskiem paliwa ma z reguły możliwość sterowania zarówno kątem wyprzedzenia wtrysku, dawką paliwa, jak i podziałem tej dawki w procesie wtrysku - w dziedzinie czasu (kąta OWK). Tę nową jakość zasilania paliwem osiągnięto nie tylko przez zastosowanie elektronicznego układu sterującego, ale także przez zastosowanie nowych elementów wykonawczych, jak na przykład nurnikowa pompa wysokiego ciśnienia, elektronicznie sterowane zawory przelewowe, zasobnik hydrauliczny i elektronicznie sterowane wtryskiwacze paliwa.

Powyższe czynniki pozwoliły na radykalną zmianę procesów sterowania wtryskiem paliwa do cylindrów i kształtowania optymalnych (np. wg kryterium minimalnego zużycia paliwa lub kryterium wymaganej emisji $\mathrm{NO}_{\mathrm{x}}$ ) warunków przebiegu procesy spalania.

Dalszy rozwój stosowania układów elektronicznego sterowania wtryskiem paliwa wymaga poznania wielu charakterystyk przebiegu wtrysku. Badania takie wykonywane są w wielu ośrodkach krajowych i zagranicznych z użyciem specjalnych stanowisk - indykatorów dawki paliwa lub bezpośrednio na silnikach badawczych [8 - 11]. Autorzy tego artykułu podjęli w AMW takie badania na stanowisku

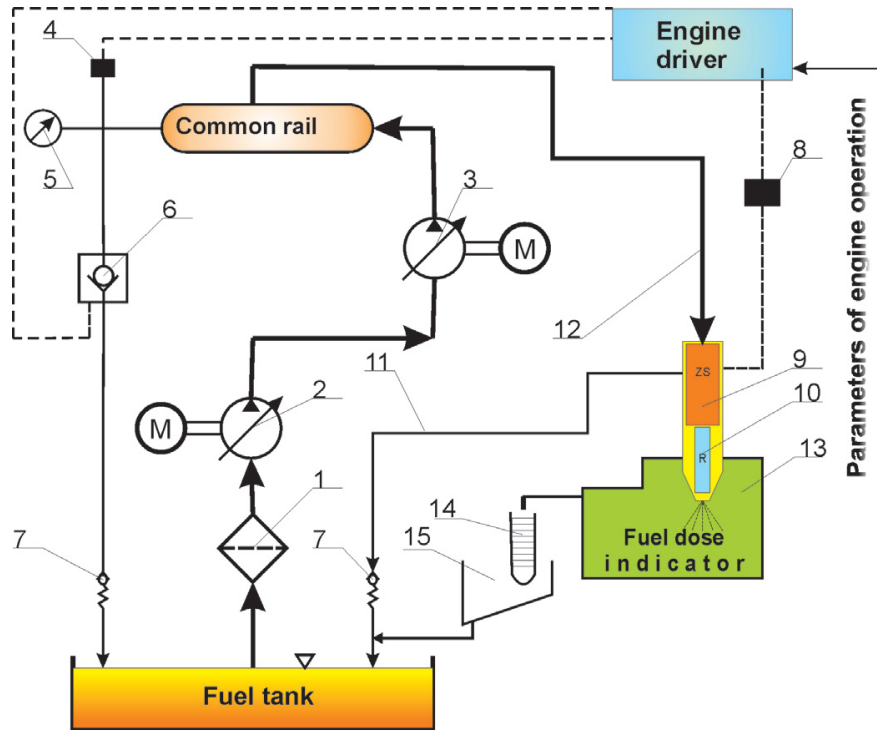

Fig. 1. The test stand of electronic control of fuel injection: 1 - filter, $2-$ low pressure pump, 3 - high pressure pump, 4 - pressure sensor, 5 - manometer, 6 - back-pressure valve with opening control, 7 - overflow valve, 8 - amplifier, 9 - injection rate controlling valve, 10 - nozzle, 11 - low-pressure fuel pipe (overflow), 12 - high pressure fuel pipe, 13 - fuel rate indicator, 14 - buret for measuring the amount of fuel, 15 - cumulative vessel

Rys. 1. Schemat stanowiska badawczego elektronicznego sterowania procesem wtrysku paliwa: 1 -filtr, 2-pompa zasilajaca paliwem, 3-pompa wysokiego ciśnienia, 4 - czujnik ciśnienia w zasobniku hydraulicznym,

5-manometr, 6-zawór zwrotny ze sterowaniem otwierania, 7-zawór przelewowy, 8-wzmacniacz sygnału, 9-zawór sterujacy dawka paliwa,

10 - rozpylacz, 11 - przewód paliwowy niskiego ciśnienia (przelewowy),

12 - przewód paliwowy wysokiego ciśnienia, 13 - indykator dawki paliwa, 14 - menzurka do pomiaru dawki paliwa, 15 - rynienka zbiorcza badawczym wykonanym przez zespół ATH w Bielsku-Białej pod kier. prof. Z. Stelmasiaka. Stanowisko to, $\mathrm{z}$ zastosowaniem indykatora dawki paliwa, zostało wykonane wg założeń projektowych autorów niniejszej publikacji odpowiednio do istniejącego w laboratorium badawczym AMW stanowiska hamownianego silnika badawczego 1DR [2].

\section{Opis stanowiska badawczego}

Jak wspomniano, stanowisko badawcze, którego schemat pokazano na rys. 1, różni się od układu zasilania silnika tym, że zamiast komory spalania zastosowano indykator dawki paliwa. Indykator pozwala zmierzyć dawkę paliwa, ale także, co najważniejsze, zarejestrować zjawiska falowe towarzyszące zasilaniu paliwem. Drugim dodatkowym urządzeniem jest sterownik, dzięki któremu można zaprogramować wielkość dawki i krotność jej podziału, czas wtrysku i przerwy pomiędzy poszczególnymi etapami wtrysku 
pressure in the common rail, engine speed, fuel temperature in different sections of the injection system, the injection time and the size of a single injection rate.

\section{The program of research}

The described test stand allows to perform tests with the use of various numbers of injections.

This paper presents the results of tests carried out under the following assumptions:

- studies were carried out at three values of fuel pressure in the common rail, i.e. 1500,1350 and 1200 bars;

- single fuel rate was equivalent to that for the engine speed at $1200 \mathrm{rpm}$;

- the maximum injection time for the engine speed adopted in the present analysis was about $25^{\circ} \mathrm{CA}$, (about $3470 \mu \mathrm{s}$ );

- for the above assumptions three fuel injection options were adopted, the first - a single injection (as in conventional systems), the second - two-stage injection $(1 / 3+2 / 3)$, the third - a three-stage injection $(0.1+0.8+0.1)$;

- for the two-stage injection a constant interval of $850 \mu$ s was assumed, while for the three-stage injection the interval between pilot injection and main injection was $700 \mu \mathrm{s}$ and the interval between the main injection and the post injection was $600 \mu \mathrm{s}$.

An injector with an electromagnetic valve (mass flow rate of approximately $0.1054 \mathrm{~g} /$ cycle) was used in the present research. As it has been shown by preliminary tests, if the interval between injections is shorter than $700 \mu$ s the fuel flow through the nozzle is not fully closed.

\section{The results of research}

Graphs in Fig. 2 to 4 present results of measurements of fuel injection which have been linearized. Due to limited data points, the to cross-correlations should be regarded as qualitative changes.

Table 1. Test results for the one-stage, two-stage and three-stage injection

Tabela 1. Zestawienie wyników pomiarów dla jednoczęściowej, dwuczęściowej i trzyczęściowej nominalnej dawki paliwa

\begin{tabular}{|c|c|c|c|c|c|c|c|c|}
\hline \multicolumn{3}{|c|}{$\begin{array}{c}\text { Single injection/ } \\
\text { dawka jednoczéściowa }\end{array}$} & \multicolumn{3}{|c|}{$\begin{array}{l}\text { Two-stage injection/ } \\
\text { dawka dwuczęściowa }\end{array}$} & \multicolumn{3}{|c|}{$\begin{array}{l}\text { Three-stage injection/ } \\
\text { dawka trzyczęściowa }\end{array}$} \\
\hline $\mathrm{q}_{\text {nom }}[\mathrm{mg}]$ & $\mathrm{p}_{\mathrm{z}}[\mathrm{MPa}]$ & $\mathrm{t}_{\mathrm{sum}}[\mu \mathrm{s}]$ & $\mathrm{q}_{\text {nom }}[\mathrm{mg}]$ & $\mathrm{p}_{\mathrm{z}}[\mathrm{MPa}]$ & $\mathrm{t}_{\mathrm{sum}}[\mu \mathrm{s}]$ & $\mathrm{q}_{\text {nom }}[\mathrm{mg}]$ & $\mathrm{p}_{\mathrm{z}}[\mathrm{MPa}]$ & $\mathrm{t}_{\mathrm{sum}}[\mu \mathrm{s}]$ \\
\hline 162.48 & 175.0 & 2800 & 143.8 & 150.0 & 3450 & 148.36 & 147.5 & 3610 \\
\hline 132.44 & 150.5 & 2500 & 135.52 & 150.0 & 3250 & 147.2 & 150.0 & 3630 \\
\hline 106.2 & 148.0 & 2000 & 148.35 & 151.0 & 3400 & 14852 & 150.0 & 3590 \\
\hline 146.84 & 149.7 & 2800 & 142.7 & 145.0 & 3450 & 149.48 & 150.0 & 3560 \\
\hline 141.64 & 148.2 & 3000 & 141.52 & 135.0 & 3600 & 142.28 & 133.0 & 3680 \\
\hline 155.76 & 133.8 & 3200 & 143.56 & 135.0 & 3650 & 150.24 & 136.0 & 3700 \\
\hline 139.6 & 130.0 & 3100 & 152.3 & 133.0 & 3900 & 135.56 & 135.0 & 3650 \\
\hline 143.0 & 134.8 & 3000 & 147.1 & 135.0 & 3700 & 157.32 & 135.0 & 3800 \\
\hline 142.56 & 119.0 & 3130 & 141.36 & 120.0 & 3850 & 141.84 & 123.0 & 3700 \\
\hline 153.2 & 120.0 & 3350 & 131.32 & 120.0 & 3600 & 150.84 & 122.0 & 3900 \\
\hline 159.0 & 118.0 & 3600 & 145.6 & 125.0 & 3800 & 148.74 & 120.0 & 3850 \\
\hline 148.0 & 125.0 & 3150 & 146.7 & 120.0 & 3950 & 146.35 & 121.0 & 3750 \\
\hline
\end{tabular}

(konstrukcja sterownika umożliwia podział dawki na pięć części). Sterownik umożliwia również pomiar i rejestrację: ciśnienia paliwa w kolektorze, prędkość obrotową silnika, temperaturę paliwa w różnych odcinkach układu zasilania, kąt OWK trwania wtrysku, wielkość pojedynczej dawki.

\section{Program badań}

Opisane stanowisko badawcze umożliwia przeprowadzenie badań przy zastosowaniu wielu sposobów podziału nominalnej dawki wtrysku paliwa.

W niniejszej pracy zamieszczono wyniki badań wykonanych według następujących założeń:

- badania przeprowadzono przy trzech wartościach ciśnienia w zasobniku hydraulicznym wynoszących 1500, 1350 i 1200 barów;

- pojedyncza dawka paliwa miała odpowiadać pracy silnika z prędkością obrotową nominalną, czyli 1200 obr/min;

- przyjętej do analizy prędkości obrotowej odpowiadał maksymalny czas na realizację wtrysku paliwa odpowiadający ok. $25^{\circ} \mathrm{OWK}$, więc dla tej prędkości obrotowej wynosi on $3470 \mu \mathrm{s}$;

- dla powyższych założeń przyjęto trzy warianty zasilania: pierwszy - pojedyncza dawka (podobnie jak w układach konwencjonalnych), drugi - dawka dwuczęściowa w proporcjach $1 / 3+2 / 3$, trzeci - dawka trzyczęściowa $\mathrm{w}$ proporcjach $-0,1+0,8+0,1$;

- dla dawki dwuczęściowej przyjęto stałą przerwę przesterowania zaworu wynoszącą $850 \mu \mathrm{s}$, natomiast dla trzyczęściowej dawki przerwa między dawką pilotującą a główną wynosiła $700 \mu \mathrm{s}$ i pomiędzy dawką główną a uzupełniającą $600 \mu \mathrm{s}$ - ze względu na ograniczenia czasowe wynikające z realizacji pełnej dawki przy nominalnej prędkości obrotowej.

Obiektem badań był elektromagnetyczny wtryskiwacz CR z zaworem sterującym o wydatku masowym ok. 0,1054 g/cykl. Jak wykazały wstępne badania, jeżeli przerwa między dawkami jest mniejsza niż $700 \mu$ s, nie ma pełnego zamknięcia przepływu paliwa przez iglicę rozpylacza.

\section{Wyniki badań}

Zestawienie wyników pomiarów dla jednoczęściowej, dwuczęściowej i trzyczęściowej nominalnej dawki paliwa podano w tabeli 1 .

Rysunki $2-4$ przedstawiają wykresy powierzchniowe, na których wyniki pomiarów parametrów wtrysku paliwa zostały zlinearyzowane. Ze względu na zbyt małą liczbę punktów pomiarowych ich wzajemne korelacje należy traktować jako zmiany jakościowe.

$\mathrm{Na}$ rysunku 5 przedstawiono wykres sekwencyjny sumarycznego czasu niezbędnego do realizacji dawki paliwa, odpowiednio jedno-, dwu- 
Graph in Fig. 5 presents total injection time for single, two-stage and three-stage injections tested with three dif-
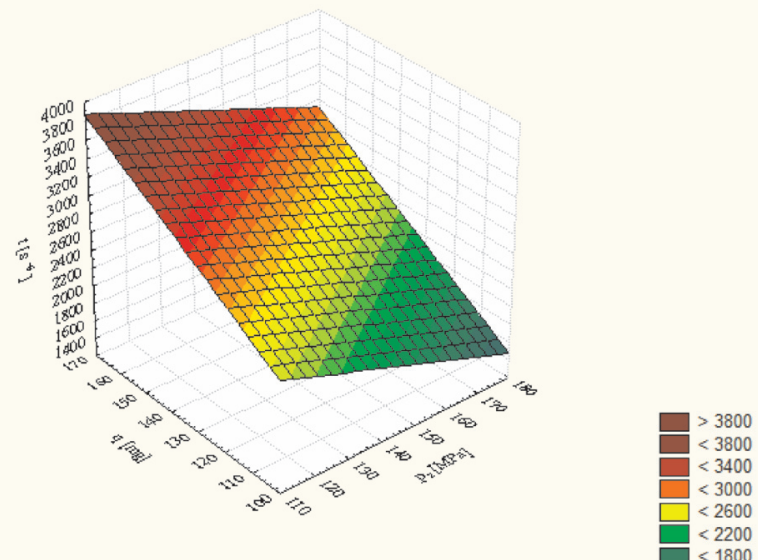

Fig. 2. Dependence of the nominal fuel dose $\mathrm{q}$ on the hydraulic pressure $\mathrm{p}_{\mathrm{z}}$ and the total time of injection $\mathrm{t}$ for a single fuel dose

Rys. 2. Wykres zależności nominalnej dawki paliwa od ciśnienia w zasobniku hydraulicznym i sumarycznego czasu wtrysku dla pojedynczej dawki paliwa
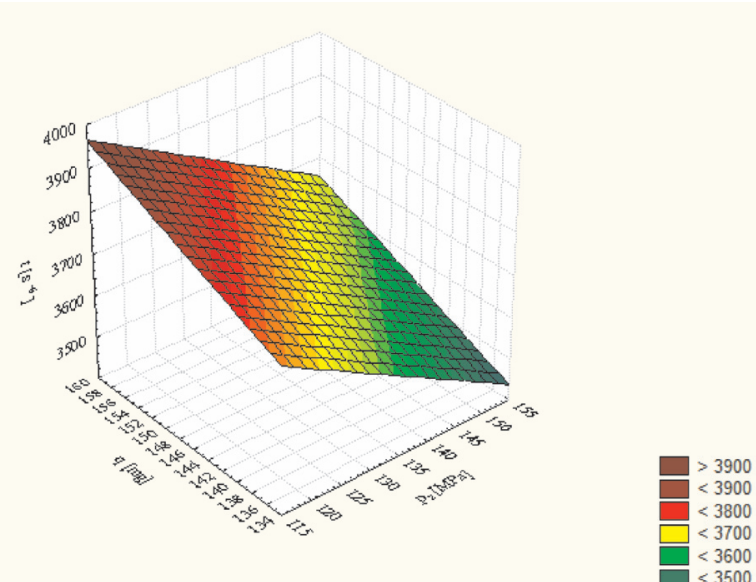

Fig. 4. Dependence of the minimum fuel dose $\mathrm{q}$ on the pressure in the common rail $\mathrm{p}_{\mathrm{z}}$ and the total time of injection $t$ for the three-piece fuel dose

Rys. 4. Wykres zależności nominalnej dawki paliwa od ciśnienia

w zasobniku hydraulicznym i sumarycznego czasu wtrysku dla trzyczęściowej dawki paliwa

ferent values of fuel pressure in the common rail. Figure 6 shows the range of fuel doses for the considered variants of fuel injection. Figure 7 shows the value of pressure in the common rail for the considered variants of fuel injection.

\section{Summary}

On the basis of the analyses reported on in the present paper, it can be stated that:

- for the analyzed nominal engine speed for which accounts the shortest time of implementation of complete fuel dose, the important parameter that can be used for selection of fuel dose in qualitative aspect is the value of pressure in the hydraulic accumulator; i trzyczęściowej dla porównywalnych nominalnych dawek przy trzech przyjętych do badań wartościach ciśnienia $\mathrm{w}$ zasobniku hydraulicznym.

Na rysunku 6 przedstawiono wielkość dawki paliwa w zależności od wariantu wtrysku wielofazowego, a na rys. 7 - ciśnienie w zasobniku w zależności od wariantu wtrysku wielofazowego.

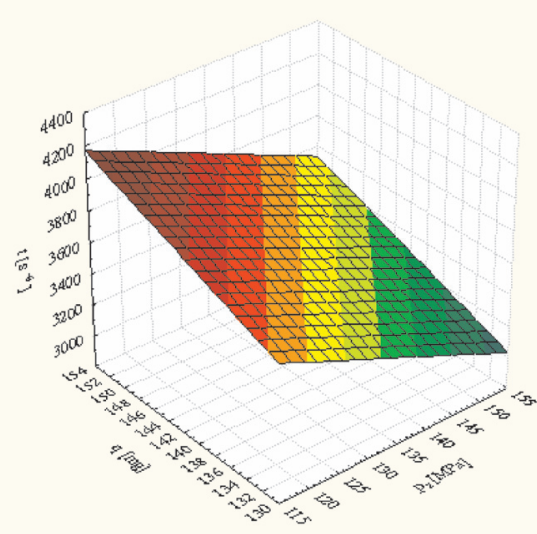

Fig. 3. Dependence of the nominal fuel dose $q$ on the pressure in the common rail $\mathrm{p}_{\mathrm{z}}$ and the total time of injection $\mathrm{t}$ for the two-piece fuel dose

Rys. 3. Wykres zależności nominalnej dawki paliwa od ciśnienia w zasobniku hydraulicznym i sumarycznego czasu wtrysku dla dwuczęściowej dawki paliwa

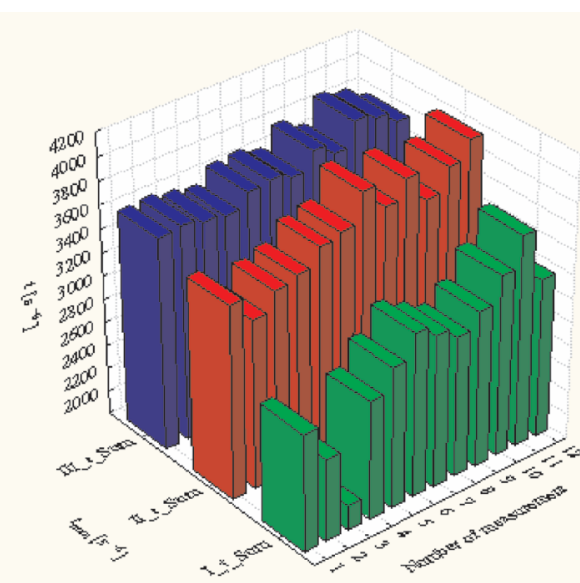

Fig. 5. Dependence of multiplicity of fuel doses on the time required for the completion of comparable fuel doses at different values of pressure $\mathrm{p}_{\mathrm{z}}$ in the common rail (measurement $1-4-$ the highest,

$$
5-8 \text { - average, } 9-12 \text { - the lowest) }
$$

Rys. 5. Zależność krotności dawki od czasu niezbędnego do jej realizacji dla porównywalnych wielkości dawek paliwa przy różnych wartościach ciśnieniach pz (pomiar 1-4-najwyższa; 5-8-średnia; $9-12$ - najniższa)

\section{Podsumowanie}

Analizując przedstawione wyniki badań, można stwierdzić, że:

- dla poddanej analizie nominalnej prędkości obrotowej, dla której przypada najkrótszy czas na realizację pełnej dawki paliwa, istotnym parametrem, który można wykorzystać 


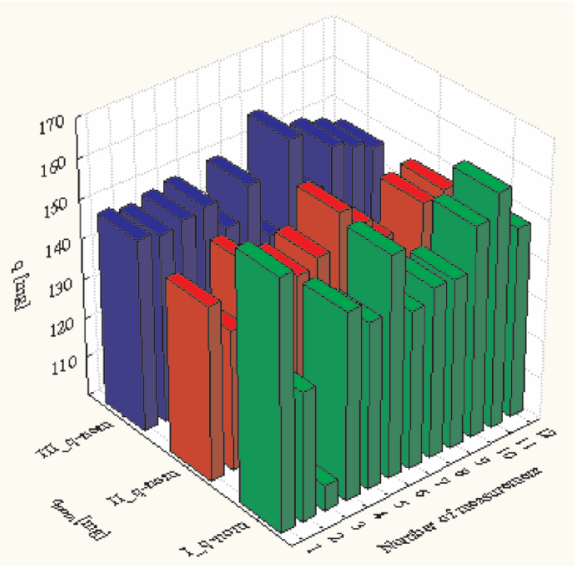

Fig. 6. Diversity of fuel delivery q for the considered injection multiplicity at different values of pressure $p_{z}$ in the common rail (measurement $1-4$ - the highest, $5-8$ - average, $9-12$ - the lowest)

Rys. 6. Zróżnicowanie dawki paliwa dla rozpatrywanych krotności wtrysku przy różnych wartościach ciśnieniach pz (pomiar 1-4-najwyższa; 5-8-średnia; $9-12$ - najniższa)

- total injection time differs for single, two-stage and threestage injections under the same value of fuel pressure in the common rail;

- it is possible to change the beginning and the end of an injection depending on the number of injections;

- significant differences in the injection rate result from complex wave phenomena, hydraulic shock, turbulence, cavitation, etc. which, in turn, are caused by fast switching on and off injection valves and the valve in the common rail.

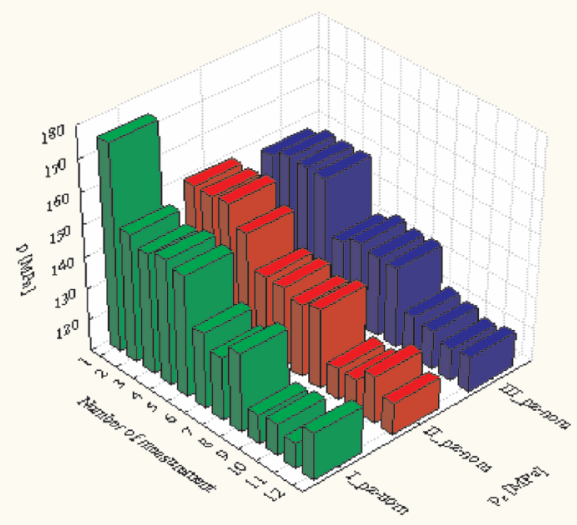

Fig. 7. Fuel pressure in the common rail for the considered multiplicity of injection

Rys. 7. Wartości ciśnień w zasobniku hydraulicznym rozpatrywanych krotności wtrysku

do doboru dawki pod względem jakościowym, jest wartość ciśnienia w zasobniku hydraulicznym;

- sumaryczny czas na realizację porównywalnych dawek paliwa przy tych samych ciśnieniach, ale różnych krotnościach podziału dawki znacznie się różnił;

- dobierając krotność dawki przy określonym ciśnieniu w zasobniku hydraulicznym, można zmieniać kąt początku i końca wtrysku paliwa w zależności od stanu pracy silnika; - znaczny rozrzut dawki nominalnej paliwa jest efektem skomplikowanych zjawisk falowych, uderzeń hydraulicznych, turbulencji, kawitacji itp., które wywoływane są szybkimi (rzędu ms) przesterowaniami zaworów sterujących we wtryskiwaczach i zasobniku hydraulicznym.

Paper reviewed/Artykut recenzowany

\section{Bibliography/Literatura}

[1] Sobieszczański M.: Modelowanie procesów zasilania w silnikach spalinowych. Zagadnienia wybrane. WKŁ, Warszawa 2000.

[2] Smolarz J., Walkowski M.: The model of steady fuel flow in the injector channels in the Common Rail systems. Scientific Journals. Maritime University of Szczecin. 2009, 17(89), s. 80-86.

[3] Balawender K., Kuszewski H., Lejda K., Ustrzycki A.: The effect of multi-phase injection on selected parameters of the common rail fuel system. Combustion Engines/Silniki Spalinowe, $\mathrm{nr}$ 4/2008 (135), s. 22-28.

[4] Informator Bosch: Zasobnikowe układy wtryskowe Common Rail. WKiŁ, Warszawa 2009.

[5] Janiszewski T., Mavrantzas S.: Elektroniczne układy wtryskowe silników wysokoprężnych. WKiŁ, Warszawa 2009.

[6] Kafar I., Merkisz J., Piaseczny L.: Fuel spray model in a medium speed marine engine - a simulation. Combustion Engines/Silniki Spalinowe, nr 3/2006 (126), s. 63-76.

Prof. Leszek Piaseczny, DSc, DEng. - Professor in the Mechanical-Electric Faculty at Naval University of Gdynia.

Prof. $d r$ hab. inż. Leszek Piaseczny - profesor na Wydziale Mechaniczno-Elektrycznym Akademii Marynarki Wojennej w Gdyni.

e-mail: piaseczny@ptnss.pl
[7] Krupa A.: State of the art of electronically controlled engines. Combustion Engines/Silniki Spalinowe, nr 1/2004 (118), s. 20-27.

[8] Kuszewski H., Lejda K., Ustrzycki A.: Determinanty dokładności dawkowania paliwa w systemie zasobnikowego układu zasilania Common Rail. Czasopismo Techniczne, z. $8-\mathrm{M} / 2008$, s. 161-172.

[9] Bocheński C.: Możliwość sterowania procesami termodynamicznymi w silnikach wysokoprężnych przy zastosowaniu akumulatorowego (Common Rail) systemu paliwa. Journal of KONES Internal Combustion Engines, 2000, s. 38-44.

[10] Zbierski K.: Układy wtryskowe Common Rail. Oficyna Wydawnicza, Łodź 2001

[11] Merkisz J.: Kierunki rozwoju spalinowych zespołów napędowych. Czasopismo Techniczne, z. 6-M/2004, s. 9-32.

Mirosław Walkowski, DEng. - doctor in the Faculty of Technical Sciences at University of Warmia and Mazury in Olsztyn.

Dr inż. Mirostaw Walkowski - adiunkt na Wydziale Nauk Technicznych Uniwersytetu Warmińsko-Mazurskiego w Olsztynie.

e-mail:mwal@interia.eu 